\title{
Skeletal Myocyte Types and Vascularity in the Black Sicilian Pig
}

\author{
S. VELOTTO ${ }^{1}$, E. VARRICCHIO ${ }^{2}$, M. R. DI PRISCO ${ }^{1}$, T. STASI $^{1}$, A. CRASTO $^{1}$ \\ ${ }^{1}$ Dipartimento di Scienze del Suolo della Pianta, dell'Ambiente e delle Produzioni Animali, Facoltà di Agraria \\ - Università degli Studi di Napoli "Federico II" \\ ${ }^{2}$ Dipartimento di Scienze Biologiche ed Ambientali - Facoltà di Scienze MM.FF.NN. \\ - Benevento Università degli Studi del Sannio
}

Received July 28, 2005

Accepted February 20, 2007

\begin{abstract}
Velotto S., E. Varricchio, M. R. Di Prisco, T. Stasi, A. Crasto: Skeletal Myocyte Types and Vascularity in the Black Sicilian Pig. Acta Vet Brno 2007, 76: 163-170.

The objective of this study was to verify the presence of giant fibres in the Black Sicilian pig skeletal muscle and to evaluate the effect of sex on histochemical and morphometric characteristics of the myocytes (myofibres) as well as vascularity of the muscle. Twenty Black Sicilian pigs (10 males, 10 females) from a farm in Sicily (Italy) were slaughtered at two years of age. Muscle tissues were obtained from three muscles: psoas major, longissimus dorsi, and trapezius. Myofibres were stained for myosin ATPase, succinic dehydrogenase, and $\alpha$-amylase-PAS. For all fibre types, area and perimeter were measured. Slow-twitch oxidative fibres, fast-twitch glycolytic fibres and fast-twitch oxidative-glycolytic fibres were histochemically differentiated; an image-analyzing system was used. The results showed no differences between males and females in percentage of the fibre types, but there were significant differences between sexes in size of all the three fibre types. Psoas major muscle had a high percentage of slow-twitch oxidative fibres and contained more capillaries per fibre and per $\mathrm{mm}^{2}$ than trapezius and longissimus dorsi, in which fast-twitch glycolytic fibres dominated. The cross-sectional area of all fibres types was larger in longissimus dorsi than in trapezius and psoas major muscles; the giant fibres were absent in all the muscles studied. Fibre type composition may contribute to the variation of meat quality.
\end{abstract}

Giant fibres, myosin ATPase, succinic dehydrogenase, capillaries

Sicilian Black Swine of Sicily's Nebrodi Mountains, locally known as the "suino nero dei Nebrodi", is considered an autochthonous breed and its meat is highly appreciated as a speciality. This pig is also related to several domestic varieties of black pig reared in Italy, particularly those of Friuli and Romagna. In recent years the black Sicilian pig population has been progressively reduced, since meat-producing animals have been selected in order to improve growth performance, in particular a rapid accretion of muscle (Lefaucheur and Gerrard 1998). Evidence suggests that this increased capacity to develop muscle has resulted in altered meat quality characteristics at least in pigs (Sellier 1997). Meat quality is a generic term used to describe proprieties and perceptions of meat (Maltin et al. 2003) and an association between meat quality and muscle fibre type is possible. Muscle fibre types may be classified based on enzymatic activity; in this study the following nomenclature was used for myofibre types: FG (fast-contracting with glycolytic metabolism), type FOG (fastcontracting with glycolytic-oxidative metabolism) and SO (slow-contracting with oxidative metabolism). The aim of this study was to evaluate the effect of sex on the histochemical and morphometric characteristics of muscle fibres on the basis of myosin ATPase, succinic dehydrogenase, and to determine the presence of giant fibres in the muscles considered. Such fibre types are distinctly enlarged and rounded with two to three times greater cross-sectional area than normal fibres (Fazarinc et al. 2002), they are found predominantly in the white muscles and in pale soft and exudative (PSE) meat. To visualize the blood capillaries the $\alpha$-amylase-PAS methods was used; such reaction stains the basal membrane of the

Address for correspondence:

Dr. Salvatore Velotto, $\mathrm{PhD}$

Dipartimento di Scienze del Suolo della Pianta,

dell'Ambiente e delle Produzioni Animali,

Facoltà di Agraria, Università degli Studi di Napoli "Federico II"

Via Università, 133-80055 - Portici (NA), Italy
Phone: + $390812539269-264$

Fax: + 390817762886

E-mail:velotto@unina.it

http://www.vfu.cz/acta-vet/actavet.htm 
capillaries. The relationship between fibre type and tenderness is complex and it is likely that other variables interact with fibre type characteristics to determine eating quality. Several studies of beef, lamb, and pork have shown a positive relation between proportions of SO fibres and either tenderness or juiciness (Maltin et al. 2001).

\section{Materials and Methods}

Twenty clinically healthy swine (10 male and 10 female) from a farm located in Sicily, were slaughtered at 2 years of age at a body mass of $135 \pm 10 \mathrm{~kg}$.

Muscle Histochemistry

The following muscles were used in the study: $\mathrm{m}$. psoas major (Pm), $\mathrm{m}$. longissimus dorsi (Ld), and $\mathrm{m}$. trapezius (Tr). Samples from each muscle were collected and immediately frozen in liquid nitrogen $\left(-196^{\circ} \mathrm{C}\right)$ and stored at $-80{ }^{\circ} \mathrm{C}$ until histochemical analyses were conducted. Transverse serial sections $(8 \mu \mathrm{m})$ were cut in a cryostat at $-20^{\circ} \mathrm{C}$ and transferred to glass cover slips.

Acid Myosin ATPase and Succinic dehydrogenase (combined histochemical staining)

The sections were stained histochemically for myosin ATPase (m-ATPase reveals muscular contraction) and succinic dehydrogenase (SDH reveals metabolism) simultaneously on the same myofibres (Solom on and Dunn 1988; Velotto et al. 2004). The method used for the combined histochemical staining (acid m-ATPase + SDH) consisted of several steps. Acid pre-incubation was performed at room temperature for $20 \mathrm{~min}$, followed by two 1 -min rinses of $\mathrm{CaCl}_{2}$ in tris-hydroxymethyl-aminomethane buffer. Nitro-blue-tetrazolium (NBT) incubation was performed for SDH activity at $37^{\circ} \mathrm{C}$ for $20 \mathrm{~min}$, followed by two rinses in distilled water. Myofibrillar acid ATPase was performed at $37^{\circ} \mathrm{C}$ at pH 9.4 for $50 \mathrm{~min}$, followed by three 30 -sec rinses in $\mathrm{CaCl}_{2}$ solution and incubation in $\mathrm{CoCl}_{2}$ for $3 \mathrm{~min}$. A standard ammonium sulphide staining of the acid ATPase procedure was performed and cover slips were applied using glycerol jelly.

Basic Myosin ATPase

The basic m-ATPase method was used for the first control procedure, consisting of sodium-cacodylate and sucrose incubation for $5 \mathrm{~min}$, followed by two 1-min rinses in $\mathrm{CaCl}_{2}$ in tris-hydroxymethyl-aminomethane buffer rinse solution. Sigma 221 and $\mathrm{CaCl}_{2}$ solutions were used for $15 \mathrm{~min}, \mathrm{pH} 10.3-10.5$, followed by two 1-min rinses in $\mathrm{CaCl}_{2}$ and tris hydroxymethyl aminomethane buffer (Merck \& Co. USA). For acid ATPase the procedure was performed at $37^{\circ} \mathrm{C}$ at a pH 9.4 for 50 min with three 30 -sec rinses in $\mathrm{CaCl}_{2}$ solution and incubation for $3 \mathrm{~min}$ in $\mathrm{CoCl}_{2}$, followed by ammonium sulphide staining. Cover slips were applied using glycerol jelly.

Succinic dehydrogenase

The SDH method was used for the second control procedure, consisting of different phases: incubation in NBT at $37^{\circ} \mathrm{C}$ for $20 \mathrm{~min}$, followed by two rinses in distilled water and formaldehyde immersion for $10 \mathrm{~min}$. Cover slips were applied using glycerol jelly.

$\alpha$-amylase-PAS (periodic acid-Schiff reaction)

To visualize blood capillaries the $\alpha$-amylase-PAS (periodic acid-Schiff reaction) method was utilized, staining their basal lamina, as employed successfully in horses, calves, and pigs (Henckel et al. 1998). The average number of capillaries adjacent to all fibre types (number of capillaries/number of counted muscle fibres) and the average number of capillaries per $\mathrm{mm}^{2}$ (number of capillaries/analyzed muscle area) were counted in longissimus dorsi, psoas major and trapezius muscles.

Fibre size

Fibre size was determined from the sections used to determine myofibres number. The area, the perimeter and the maximum and minimum diameter were measured using an image-analysing system (Zeiss, Kontron, KS 300). For each muscle not less than 200 fibres measured from eight random fields were determined. The average fibre size was calculated.

Statistical Analysis

Data were processed by analysing the variances, and means were estimated by following the general linear model (Proc GLM; SAS, 1992) in which the factors considered are fixed and the effect of the other factors is expressed as deviation from the general average $(\mu)$. The model used was:

$\mathrm{y}_{\mathrm{ijkl}}=\mu+\mathrm{Sex}_{\mathrm{i}}+\mathrm{Mu}_{\mathrm{j}}+\mathrm{Ft}_{\mathrm{k}}+\left(\mathrm{sex}^{*} \mathrm{Ft}\right)_{\mathrm{ik}}+(\mathrm{Mu} * \mathrm{Ft})_{\mathrm{ik}}+\mathrm{e}_{\mathrm{ijkl}}$;

$\mathrm{y}_{\mathrm{ijklm}}=$ value of $\mathrm{I}^{\text {th }}$ relative observation to the $\mathrm{k}^{\text {th }}$ fibre type of the $\mathrm{j}^{\text {th }}$ muscle; of $\mathrm{i}^{\mathrm{th}}$ sex.

$\mathrm{Sex}_{\mathrm{i}}=$ fixed effect of the $\mathrm{i}^{\mathrm{th}} \operatorname{sex}(\mathrm{i}=1,2)$.

$\mathrm{Mu}_{\mathrm{j}}=$ fixed effect of the $\mathrm{j}^{\text {th }}$ muscle $(\mathrm{j}=1,2,3)$.

$\mathrm{Ft}_{\mathrm{k}}=$ fixed effect of the $\mathrm{k}^{\mathrm{th}}$ fibre type $(\mathrm{k}=1,2,3)$.

$(\mathrm{Sex} * \mathrm{Ft})_{\mathrm{ik}}=$ fixed effect of the $\mathrm{i}^{\mathrm{t}^{\mathrm{t}}}$ sex with the $\mathrm{k}^{\text {th }}$ fibre type.

$(\mathrm{Mu} * \mathrm{Ft})_{\mathrm{jk}}=$ fixed effect of the $\mathrm{j}^{\text {th }}$ muscle with the $\mathrm{k}^{\text {th }}$ fibre type.

$\mathrm{e}_{\mathrm{ijkl}}=$ residual error

The significance between the mean values was evaluated using Student's $t$-test. 


\section{Results}

Histochemical results revealed three fibre types: FG, with high m-ATPase activity and low oxidative activity; FOG, with moderate m-ATPase activity and intermediate oxidative activity; and SO, with low m-ATPase and high oxidative activity (Plates I, II, III, Figs 1, 2, 3, 4, 5 and 6). Fig. 7 shows the percentage of the fibre types in the muscle considered. Pm and $\operatorname{Tr}$

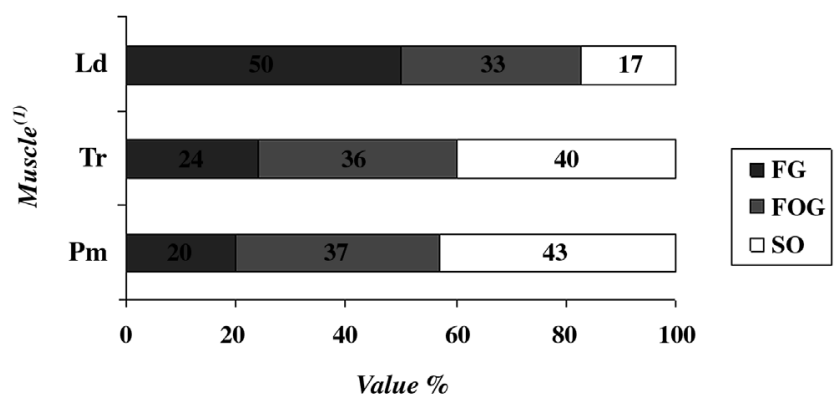

Fig. 7. Percentage specific type skeletal myofibre in muscles examined

muscles show similar percentage of muscle fibre types, the SO is the highest (43 vs. 40 ), followed by the FOG (37 vs. 36 ), and the FG fibres (20 vs. 24). In the Ld muscle the FG is the highest (50\%), followed by the FOG (33\%), and the SO fibres (17\%). In all the muscles studied, there were no giant fibres. No differences were noticed between males and females with regard to the percentage of the fibre types (Fig. 8). The muscles examined showed a unique distribution of fibres composed of clusters of SO fibres, which were surrounded by FOG and FG fibres (Plate III, Figs 5 and 6). The results of the analysis of variance showed significant muscle $\times$ fibre and sex $\times$ fibre interaction $(P<0.001)$ for the morphometric characteristics evaluated. In particular, the dimensions of FOG, FG and SO fibres in the Ld muscle were higher than in Pm and Tr muscles (Table 1). The differences between Ld and

Table 1. Mean value and variation coefficient (v.c., \%) of morphometric characteristics of fibre types in the respective muscles

\begin{tabular}{|c|c|c|c|c|c|c|}
\hline \multirow{3}{*}{ Muscle* } & \multicolumn{6}{|c|}{ Fibre Types } \\
\hline & \multicolumn{2}{|c|}{ FG } & \multicolumn{2}{|c|}{ FOG } & \multicolumn{2}{|c|}{$\mathrm{SO}$} \\
\hline & mean & v.c., $\%$ & mean & v.c., $\%$ & mean & v.c., $\%$ \\
\hline \multicolumn{7}{|c|}{ Area $/ \mu m^{2}$} \\
\hline $\mathrm{Pm}$ & $2923.17^{A}$ & 38 & $2061.25^{\mathrm{A}}$ & 38 & $2923.73^{A}$ & 38 \\
\hline $\operatorname{Tr}$ & $4444.23^{\mathrm{B}}$ & 29 & $3757.20^{\mathrm{B}}$ & 39 & $5154.86^{\mathrm{B}}$ & 40 \\
\hline $\mathrm{Ld}$ & $6000.00^{C}$ & 40 & $4226.45^{\mathrm{C}}$ & 41 & $6731.58^{\mathrm{C}}$ & 40 \\
\hline \multicolumn{7}{|c|}{ Perimeter/ $\mu \mathrm{m}$} \\
\hline $\mathrm{Pm}$ & $260.36^{\mathrm{A}}$ & 20 & $224.59^{\mathrm{A}}$ & 19 & $257^{\mathrm{A}}$ & 19 \\
\hline $\operatorname{Tr}$ & $321.33^{\mathrm{B}}$ & 14 & $294.98^{\mathrm{B}}$ & 19 & $328.31^{\mathrm{B}}$ & 20 \\
\hline $\mathrm{Ld}$ & $363.89^{\mathrm{C}}$ & 20 & $309.68^{\mathrm{C}}$ & 20 & $370.47^{C}$ & 20 \\
\hline
\end{tabular}

Letters in column indicate significance level of $P<0.001$ (A vs. B vs. C)

$* \mathrm{Pm}=\mathrm{m}$. psoas major; $\mathrm{Tr}=\mathrm{m}$. trapezius; $\mathrm{Ld}=\mathrm{m}$. longissimus dorsi

Tr, with regard to fibre area were $26 \%$ for FG (6000.00 vs. $4444.23, P<0.001), 11 \%$ for FOG (4226.45 vs. $3757.20, P<0.001)$ and $23 \%$ for SO (6731.58 vs. $5154.86, P<0.001)$. The differences between $\mathrm{Ld}$ and Pm, with regard to fibre area were $51 \%$ for FG (6000.00 vs. $2923.17, P<0.001), 51 \%$ for FOG (4226.45 vs. $2061.25, P<0.001)$ and $57 \%$ for SO 


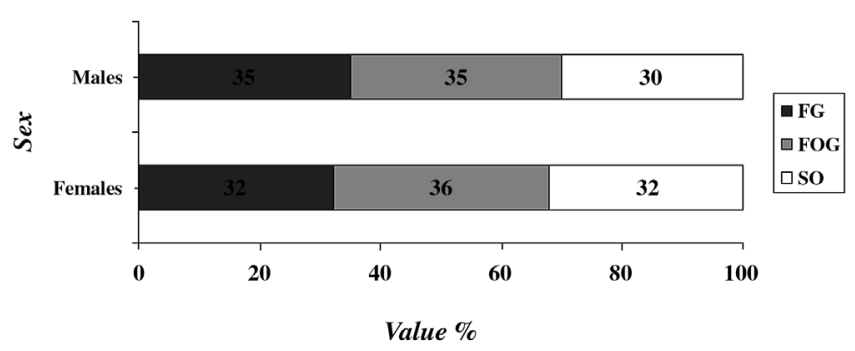

Fig. 8. Influence of sex upon percentage specific type skeletal myofibre, grouped for muscles examined

Table 2. Mean value and variation coefficient (v.c.,\%) of morphometric characteristics of fibre types in relation to sex

\begin{tabular}{|c|c|c|c|c|c|c|}
\hline \multirow{3}{*}{ Sex } & \multicolumn{6}{|c|}{ Fibre Types } \\
\hline & \multicolumn{2}{|c|}{ FG } & \multicolumn{2}{|c|}{ FOG } & \multicolumn{2}{|c|}{$\mathrm{SO}$} \\
\hline & mean & v.c., $\%$ & mean & v.c.,\% & mean & v.c., $\%$ \\
\hline \multicolumn{7}{|c|}{ Area $/ \mu \mathrm{m}^{2}$} \\
\hline Males & $4670.11^{\mathrm{a}}$ & 50 & $3731.08^{\mathrm{A}}$ & 51 & $5511.64^{\mathrm{A}}$ & 49 \\
\hline Females & $4015.31^{\mathrm{b}}$ & 52 & $2739.34^{\mathrm{B}}$ & 55 & $4135.63^{\mathrm{B}}$ & 59 \\
\hline \multicolumn{7}{|c|}{ Perimeter $/ \mu \mathrm{m}$} \\
\hline Males & $300.0^{\mathrm{a}}$ & 24 & $268.04^{\mathrm{A}}$ & 24 & $314.31^{\mathrm{A}}$ & 22 \\
\hline Females & $252.11^{\mathrm{b}}$ & 25 & $206.60^{\mathrm{B}}$ & 25 & $244.58^{\mathrm{B}}$ & 26 \\
\hline
\end{tabular}

Letters in column indicate significance level of $P<0.05$ (a vs. b) and $P<0.001$ (A vs. B)

(6731.58 vs. $2923.73, P<0.001)$. Significant differences between sexes for size of three fibre types (SO, FOG, FG) were noticed; in particular in contrast with the study of Larzul et al. (1997) our study showed that the dimensions of FOG FG and SO fibres in the males are higher than in the females (Table 2 ). The differences between males and females with regard to fibre area were $14 \%$ for FG (4670.11 vs. $4015.31, P<0.05), 27 \%$ for FOG $(3731.08$ vs. $2739.34, P<0.001)$ and $25 \%$ for SO (5511.64 vs. $4135.63, P<0.001)$. Psoas major muscle contained on average $569 \pm 75.87$ capillaries per $\mathrm{mm}^{2}$ and $1.5 \pm 0.2$ capillaries per fibre; Trapezius muscle contained on average $542 \pm 30.13$ capillaries per $\mathrm{mm}^{2}$ and $1.5 \pm 0.1$ capillaries per fibre and longissimus dorsi muscle contained on average $176.9 \pm 35.38$ capillaries per $\mathrm{mm}^{2}$ and $1 \pm 0.2$ capillaries per fibre.

\section{Discussion}

Skeletal muscle is composed of fibres exhibiting different contractile and metabolic properties and influencing the post-mortem proprieties of meat (Fiedler et al. 2004).

Fibre type classification is usually based on histochemical staining of serial cross sections. On this basis, mammalian muscle fibres are commonly classified as three major types. Type I, or SO fibres have a small diameter and are red cells containing relatively slow-acting myosin ATPase and hence they contract slowly. Such fibres have numerous mitochondria, mostly located close to the periphery of the fibre, near to the blood capillaries providing a rich supply of oxygen and nutrients. These fibres possess a high capacity for oxidative metabolism, are fatigue resistant and capable of repeated contractions for prolonged intervals. Type IIB or FOG fibres are pale, containing little myoglobin. They possess fastacting myosin ATPase and their contraction speed is relatively fast. They have fewer mitochondria, a poorer blood supply, but greater glycogen and phosphocreatine stores 
compared with the type I fibres. A high activity of glycogenolytic and glycolytic enzymes endows type IIB fibres with a high capacity for rapid ATP production in the absence of oxygen. As a result, lactic acid accumulates in these fibres and they fatigue rapidly. Hence, these fibres are best suited for providing powerful contractions for short intervals. The metabolic characteristics of type IIA fibres lie between the properties of the I and IIB fibre types. They contain fast-acting myosin ATPase as with the type IIB fibres, but they also have an oxidative capacity, much as the type I fibres.

Several studies have demonstrated that muscle fibre type composition contributes to the variation in meet quality. In the pig there are light and dark muscles. Dark muscles contain predominantly type I and type IIA muscle fibres, while light muscles are primarily type IIB. Longissimus dorsi, gluteus medius, rectus femoris, biceps femoris, quadriceps femoris, vastus lateralis, and semimembranosus are light muscles. Masseter, trapezius, vastus intermedius, and triceps brachii are dark muscles. Some muscles, such as the semitendinosus, are divided into light and dark parts (Handel and Stickland 1986). In agreement with the study of Lefaucheur and Vigneron (1986), we noticed that most muscles of the pig exhibit a highly organized pattern and a unique distribution of fibre types consisting of islets of slow-twitch (type I) fibres surrounded by an internal rosette of IIA fibres and an external ring of type IIB fibres. Several studies have described the ontogenesis of this fibre type distribution. Pig myogenesis, as in many mammalian species, is a biphasic phenomenon with the consequent formation of two generations of muscle fibres (Lefaucheur et al. 1995). Muscle type, location, and function are undoubtedly the most important factors influencing fibre type composition within an animal (Lefaucheur and Gerrard 1998). The presence of different fibre types may vary greatly in relation to different functional role performed by the muscles. Generally, deep muscles involved in maintaining posture are more oxidative and contain more type I fibres than more superficial muscles involved in rapid movements (Ono et al. 1995). In particular, our study shows that Pm muscle and Tr muscles have a high percentage of SO fibre types. Research has indicated that high oxidative capacity of muscle, glycogen, and triglycerides make meat tender and juicy (Karlsson et al. 1993). The presence of such fibre types is justified by the fact that psoas major muscle is an adductor-abductor of the femur.

When this muscle acts with a fixed anchor in the lumbar region it flexes the thigh visà-vis the pelvis, whereas, when it acts with a fixed anchor on the femur it flexes the lumbar region. Trapezius muscle is an abductor of the shoulder; its cervical portion pulls on the scapula in dorsocranial direction, its thoracic portion aids this movement by oscillating the dorsal part of the scapula in caudal direction. In agreement with the study of Fazarin c et al. (2002), our study shows that the longissimus muscle is a typical white muscle in which fast-twitch glycolytic fibres dominate. It has been suggested that muscles with a high density of anaerobic fibres have a higher probability of being of poor eating quality, due to the more rapid accumulation of lactate and decline in $\mathrm{pH}$ (V an Laack et al. 2001). Moreover, Klosowska et al. (1985) reported that the more glycolytic fibres in longissimus dorsi, the higher the drip loss and the lower the water binding capacity of the meat. Such muscle is an extensor of the rachis and it supports the bridge that constitutes the vertebral column between the pelvic and thoracic limbs. In a study on the longissimus lumborum of four breeds (German Landrace, Large white, Leicoma and Schwerfurter) considering the fibre type composition, Fiedler et al. (2004) reported that the muscles consisted mainly of white, glycolytic fibre types (77\%); the frequencies of the red and intermediate fibres were low, 11.1 and $11.2 \%$, respectively. The frequency of giant fibres was very low $(0.005 \%)$ and showed very high standard error. To the contrary, in our study no giant fibres were observed. The absence of such fibre types could be explained by the fact that the Sicilian Black swine are farmed at extensive or semi-extensive farms, show 
disease resistance, and are capable to adapt to harsh climate conditions. Giant fibres have been frequently observed in the muscles of domestic pigs, a higher frequency of giant fibres was also noticed in stress-susceptible pigs (Fiedler et al. 1999). It could be assumed that such large/giant fibre types originate from the glycolytic fibres, as a consequence of increased intracellular lactate accumulation during post-mortem glycolysis. This leads to hydropic swelling of mitochondria and sarcoplasmic reticulum and myofibrillar destruction. Muscle fibre hypertrophy occurs in animals in cases of congenital neuromuscular diseases and nutritional dystrophies, conditions that result in compensatory hypertrophies of some muscle fibres ( $\mathrm{J} \mathrm{u} \mathrm{b} \mathrm{b}$ et al. 1985). In a study on local Krško polje pigs, Fazarinc et al. (2002) reported the occurrence of giant fibres in porcine longissimus muscle is strongly correlated with the muscle $\mathrm{pH}$, an indicator of early post-mortem glycolysis, leading to lactate formation in the tissue. Lactate is osmoticly active, binding intercellular water, which results in interstitial oedema and PSE condition of the muscle. Gender has been reported to have no effect on muscle fibre number in mice and meat producing animals (Dwyer et al. 1994). However, it can strongly influence muscle fibre type composition (Lefaucheur and Gerrard 1998). Our study shows that there are no differences between males and females with regard to the percentage of the fibre types, but significant differences between sexes in the size of all three fibre types were noticed; specifically, the females showed larger fibres than the males. For pigs, several studies have documented differences between females and castrated males (barrows). Generally, females exhibit larger fibres, with no difference in fibre type percentages and relative areas (Larzul et al. 1997). Fibre type percentages were also found to be similar in the longissimus muscle of boars (Solo mon et al. 1990). In a study carried out on the longissimus muscle from 165 female and 152 intact male Large White pigs of $70 \mathrm{~kg}$, Lefaucheur and Gerrard (1998) found a significantly higher relative area of type I fibres in intact male pigs $(7.6 \pm 2.2 \%)$ than in females $(6.7 \pm 2.5 \%)(P<0.001)$, suggesting that castration effected shortly after birth decreases relative area of type I fibres in pigs.

Regarding the fibre size, our study highlights that the cross-sectional area of all fibre types was larger in longissimus dorsi than in trapezius and psoas major muscles. Von Lengerken et al. (2002) in their study on the longissimus dorsi muscle noticed that the mean fibre diameter of all types was significantly increased in pigs developing PSE meat after slaughter compared to pigs of normal meat quality. This observation indicates that breeding selection for high lean meat yield has resulted in hypertrophy of the muscle fibres. Moreover, Weiler et al. (1995) in their study on European domestic pigs noticed that for all fibre types, domestic pigs had nearly three-fold larger fibres than wild pigs. Type-I fibres tended to be the smallest fibres in domestic pigs, but the largest fibres in wild pigs, which may be due to "long-term training" effects in the free-ranging animals. The majority of investigations have demonstrated a strong relationship between muscle capillarity and oxidative capacity (Poole 1996). Moreover, Torrella et al. (1998) in their study on the wild common coot noticed a linear relationship between capillary and fibre densities. The capillary supply, or capillarity, can be expressed as the amount of capillaries per $\mathrm{mm}^{2}$ (capillary density) or per muscle fibre (capillary to fibre ratio). In both cases, the results depend on the cross-sectional areas of the muscle fibres (Dingboom 2002). Our study shows that the psoas major muscle (dark muscle) contains more capillaries per fibre and per $\mathrm{mm}^{2}$ than the trapezius and longissimus dorsi. In most cases the number of capillaries around type I fibres is higher than around type II fibres (Karlström et al. 1991). The capillary supply of muscles is of importance for "exercise tolerance" in horses (Karlström et al. 1991). Furthermore, it is known that when muscle activity increases, the tissue reacts with angiogenesis. 


\section{Typy svalových vláken a jejich vaskularizace u černého sicilského prasete}

Cílem této studie bylo ověřit přítomnost obřích vláken ve skeletální svalovině u černého sicilského prasete a zhodnotit vliv pohlaví na histochemické a morfometrické vlastnosti myofibril a vaskularizaci svalů. Dvacet černých sicilských prasat (10 samců, 10 samic) ze statku na Sicílii (Itálie) bylo poraženo ve věku dvou let. Svalová tkáň byla získána ze tří svalů: $\mathrm{m}$. psoas major, m. longissimus dorsi, a m. trapezius. Myofibrily byly barveny na myosin ATPázu, sukcinyl dehydrogenázu, a $\alpha$-amylázu-PAS. U všech tř́i typů vláken byla změřena plocha a obvod. Oxidativní pomalá vlákna, glykolytická rychlá vlákna a oxidativně-glykolytická vlákna byla rozlišena histochemicky s použitím systému analýzy obrazu. Výsledky neprokázaly žádné rozdíly mezi samci a samicemi v procentu typů vláken, avšak byly nalezeny významné rozdíly mezi pohlavími co do velikosti všech tř́ typů vláken. M. psoas major měl vysoké procento oxidativních vláken a obsahoval více kapilár na jedno vlákno a na $\mathrm{mm}^{2}$ než $\mathrm{m}$. trapezius a $\mathrm{m}$. longissimus dorsi, u nichž převažovala rychlá glykolytická vlákna. Plocha průřezu všech typů vláken byla větší u svalu m. longissimus dorsi než u m. trapezius a m. psoas major; obří vlákna u všech zkoumaných svalů chyběla. Složení typu vláken může přispívat ke kolísání kvality masa.

\section{References}

DINGBOOM EG 2002: Equine locomotory muscles: postnatal development and the influence of exercise. Tekst, Proefschrift Universiteit, Utrecht, 89 p.

DWYER CM, STICKLAND NC, FLETCHER JM 1994: The influence of maternal nutrition on muscle fibre number development in the porcine fetus and on subsequent postnatal growth. J Anim Sci 72: 911-917

FAZARINC G, CANDEK-POTOKAR M, URSIC M, VERECL M, POGACNIK A 2002: Giant muscle fibres in pigs with different Ryr1 genotype. Anat Histol Embryol 31: 367-371

FIEDLER I, DIETL G, REHFELDT C, WEGNER J, ENDER K 2004: Muscle fibre traits as additional selection criteria for muscle growth and meat quality in pigs results of a simulated selection. J Anim Breed Genet 121: 331-344

FIEDLER I, ENDER K, WICKE M, MAAK S, VON LENGERKEN G, MEYER W 1999: Structural and functional characteristics of muscle fibres in pigs with different malignant hyperthermia susceptibility (MHS) and different meat quality. Meat Sci 53: 9-15

HANDEL SE, STICKLAND NC 1986: "Giant" muscle fibres in skeletal muscle of normal pigs. J Comp Pathol 96: $447-57$

HENCKEL P, DUCRO B, OKSBJERG N, HASSING L 1998: Objectivity of two methods of differentiating fibre types and repeatability of measurements by application of the TEMA image analysis system. Eur J Histochem 42: 49-62

JUBB KVF, KENEDDY PC, PALMER N 1985: Pathology of domestic animals. New York Academic Press Inc. pp. 305-377

KARLSSON A, ENFÄLT AC, ESSEN-GUSTAVSSON B, LUNDSTRÖM K, RYDHMER L, STERN S 1993: Muscle histochemical and biochemical properties in relation to meat quality during selection for increased lean tissue growth rate in pigs. J Anim Sci 71: 930- 938

KARLSTRÖM K, ESSÉN-GUSTAVSSON B, LINDHOLM A, PERSSON SGB 1991: Capillary supply in relation to muscle metabolic profile and cardiocirculatory parameters. Equine Ex Physiol 3: 239-244

KLOSOWSKA D, KLOSOWSKI B, FIEDLER I, WEGNER J 1985: Veränderung in der Fasertypenverteilung und Muskelfasergrösse im M. longissimus dorsi der Schweine während des Wachstums und Beziehungen zwischen histologischen Merkmalen und Schlachtkörperkriterien. Arch Tierz 28: 171-180

LARZUL C, LEFAUCHEUR L, ECOLAN P, GOGUÉ J, TALMANT A, SELLIER P, LE ROY P, MONIN G 1997: Phenotypic and genetic parameters for Longissimus muscle fibre characteristics in relation to growth, carcass, and meat quality traits in Large White pigs. J Anim Sci 75: 3126-3137

LEFAUCHEUR L, VIGNERON P 1986: Postnatal changes in some histochemical and enzymatic characteristics of three pig muscles. Meat Sci 16: 119-216

LEFAUCHEUR L, EDOM F, ECOLAN P, BUTLER-BROWNE GS 1995: Pattern of muscle fibre type formation in the pig. Develop Dynam 203: 27-41

LEFAUCHEUR L, GERRARD DE 1999: Muscle fibre plasticity in farm mammals. Proc Am Soc Anim Sci, 2000. Available at: http://www.asas.org/jas/proceedings/0307.pdf. Accessed May 2, 2001.

MALTIN CA, LOBLEY GE, GRANT CM, MILLER LA, KYLE DJ, HORGAN GW, MATTHEWS KR, SINCLAIR KD 2001: Factors influencing beef eating quality - 2. Effects of nutritional regimen and genotype on muscle fibre characteristics. Anim Sci 72: 279-287 
MALTIN C, BALCERZAK D, TILLEY R, DELDAY M 2003: Determinants of meat quality: tenderness. Proc Nutr Soc-Engl Scot 62: 337-347

ONO Y, SOLOMON MB, EVOCK-CLOVER CM, STEELE NC, MARUYAMA K 1995: Effects of porcine somatotropin administration on porcine muscles located within different regions of the body. J Anim Sci 73 : 2282-2288

POOLE DC, MATHIEU-COSTELLO O 1996: Relationship between fibre capillarization and mitochondrial volume density in control and trained rat soleus and plantaris muscles. Microcirculation- London 3(2): 175-186 SAS Institute Inc. 1992: SAS User's Guide: Statistics. SAS inst. Inc., Cary, NC

SELLIER P 1997: Genetics of meat and carcass traits. Genet Pig 15: 1-51

SOLOMON MB, DUNN MC 1988: Simultaneous histochemical determination of three fibre types in single section of ovine, bovine and porcine skeletal muscle. J Anim Sci 66: 255-264

SOLOMON MB, CAMPBELL RG, STEELE NC 1990: Effect of sex and exogenous porcine somatotropin on Longissimus muscle fibre characteristics of growing pigs. J Anim Sci 68: 1176-1181

TORRELLA JR, FOUCES V, PALOMEQUE J, VISCOR G 1998: Capillarity and fibre types in locomotory muscles of wild common coots, Fulica atra. J Morphol 237: 147-164

VAN LAACK RLJM, STEVENS SG, STALDER KJ 2001: The influence of ultimate pH and intramuscular fat content on pork tenderness and tenderization. J Anim Sci 79: 392-397

VELOTTO S, CRASTO A 2004: Histochemical and morphometrical characterization and distribution of fibre types in four muscles of ostrich (Struthio camelus). Anat Histol Embryol 33: 251-256

VON LENGERKEN G, MAAK S WICKE M 2002: Muscle metabolism and meat quality of pigs and poultry Vet Zootech 20: $82-86$

WEILER U APPELL HJ, KREMSER M, HOFACKER S, CLAUS R 1995: Consequences of selection on muscle composition. A comparative study on gracilis muscle in wild and domestic pigs. Anat Histol Embryol 24: $77-80$ 
Plate I

Velotto S.: . et al.: Skeletal Myocyte ... pp. 163-170

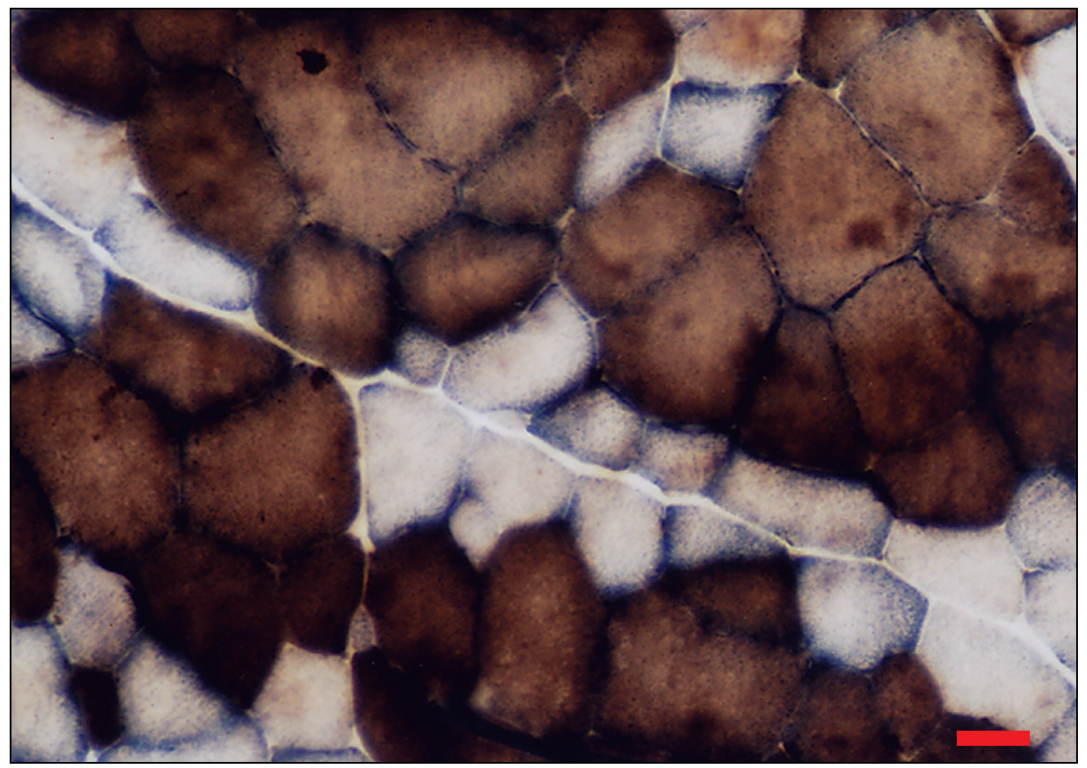

Fig. 1. M. psoas major (male). Light microscopy, m-ATPase + SDH histochemical staining of skeletal myofibres revealing three myofibre types: slow oxidative ( $\mathrm{SO}$, darkest); fast oxidative glycolytic (FOG, intermediate intensity) and fast glycolytic (FG, lightest). Note pattern of fascicles of slow oxidative myofibres separated by fast myofibres. Transverse section, bar $=40 \mu \mathrm{m}$

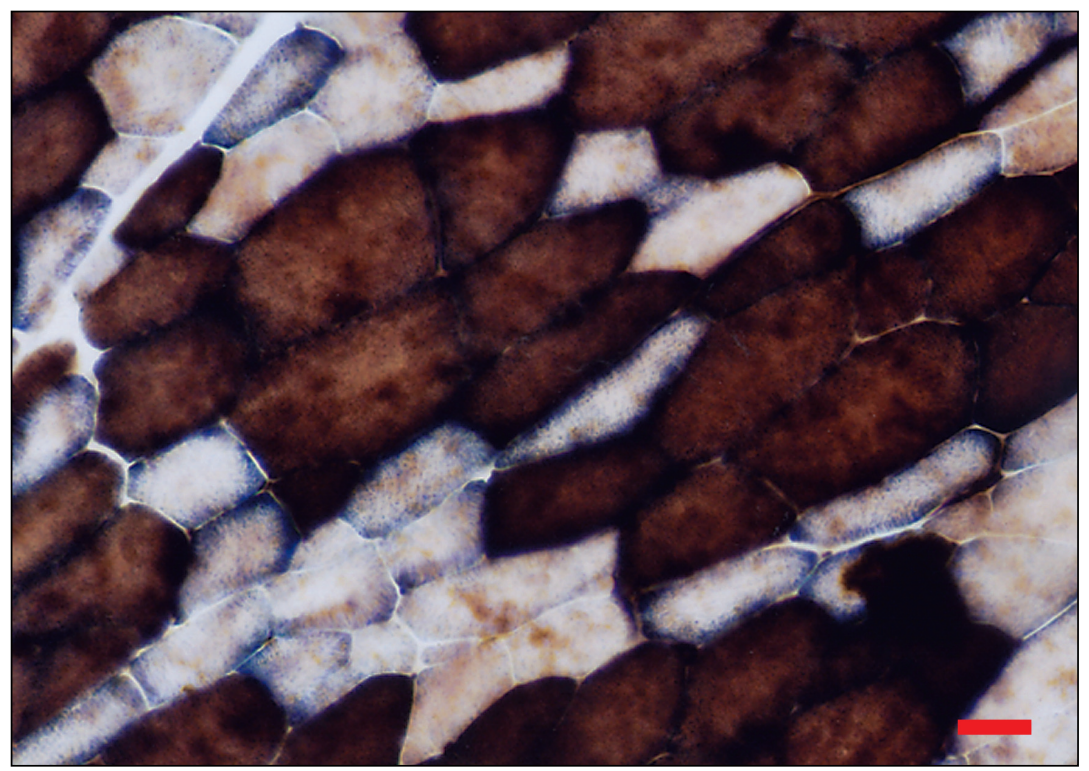

Fig. 2. M. psoas major (female). Light microscopy, m-ATPase + SDH histochemical staining of skeletal myofibres revealing three myofibre types: slow oxidative ( $\mathrm{SO}$, darkest); fast oxidative glycolytic (FOG, intermediate intensity) and fast glycolytic (FG, lightest). Oblique section, bar = $40 \mu \mathrm{m}$ 


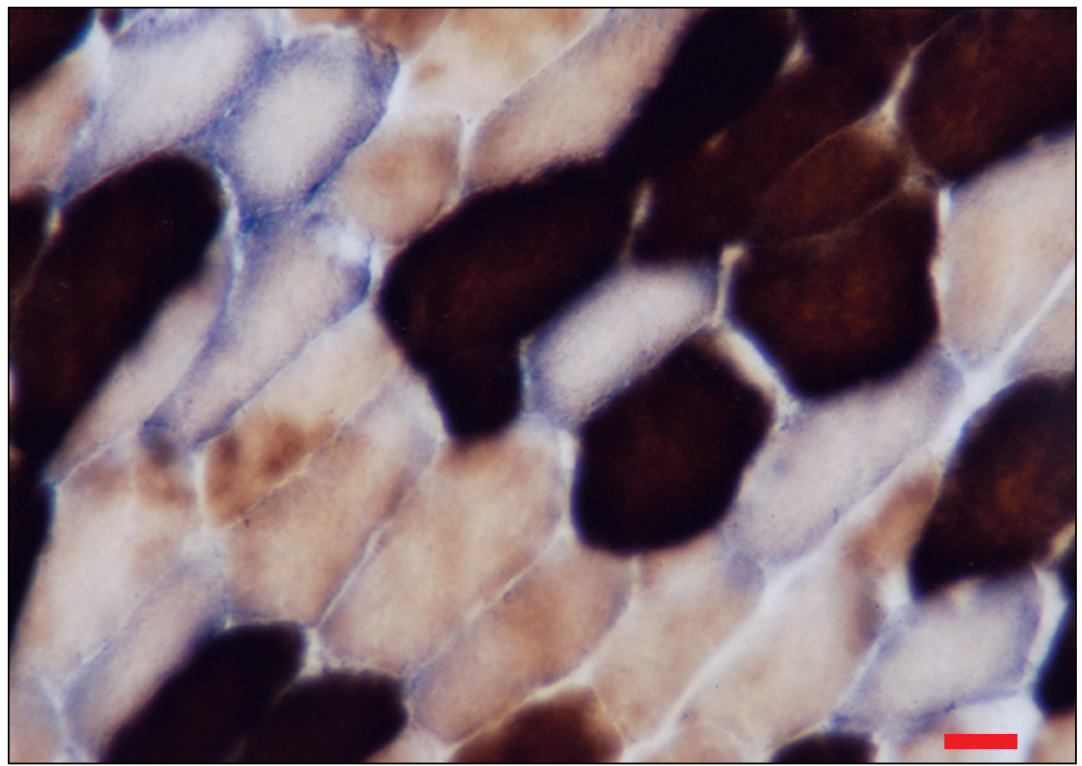

Fig. 3. M. trapezius (male). Light microscopy, m-ATPase + SDH histochemical staining of skeletal myofibres revealing three myofibre types: slow oxidative (SO, darkest); fast oxidative glycolytic (FOG, intermediate intensity) and fast glycolytic (FG, lightest). Oblique section, bar $=40 \mu \mathrm{m}$

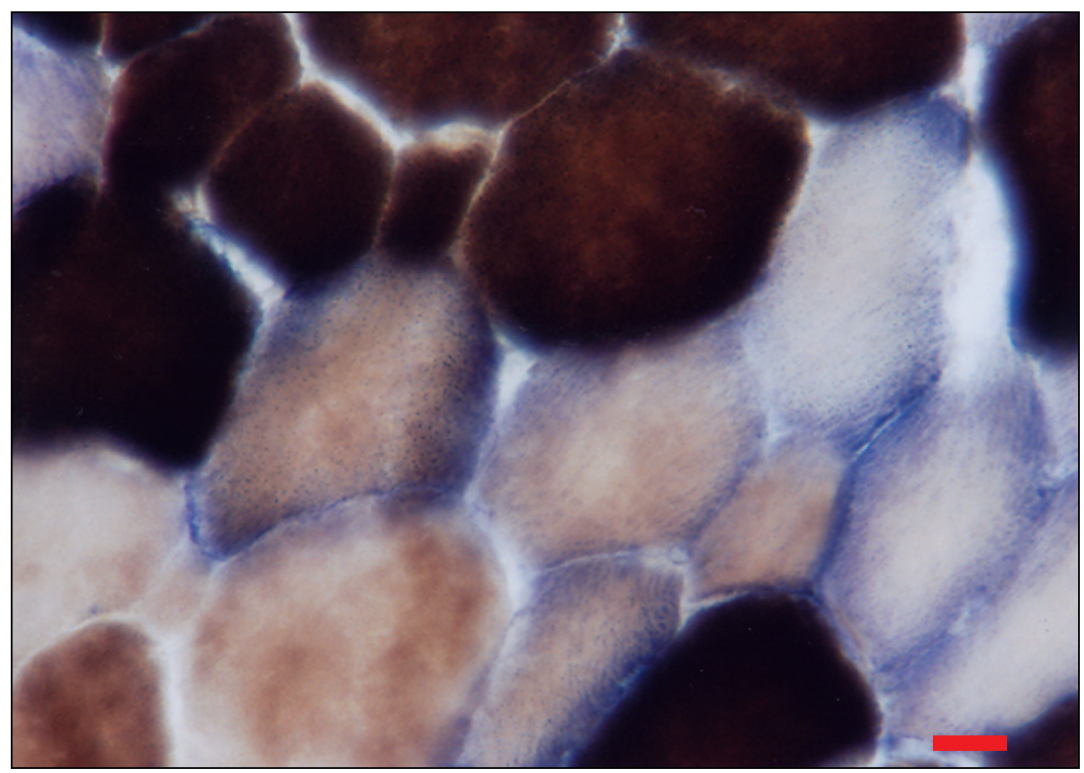

Fig. 4. M. trapezius (female) Light microscopy, m-ATPase + SDH histochemical staining of skeletal myofibres revealing three myofibre types: slow oxidative (SO, darkest); fast oxidative glycolytic (FOG, intermediate intensity) and fast glycolytic (FG, lightest). Transverse section, bar $=25 \mu \mathrm{m}$ 


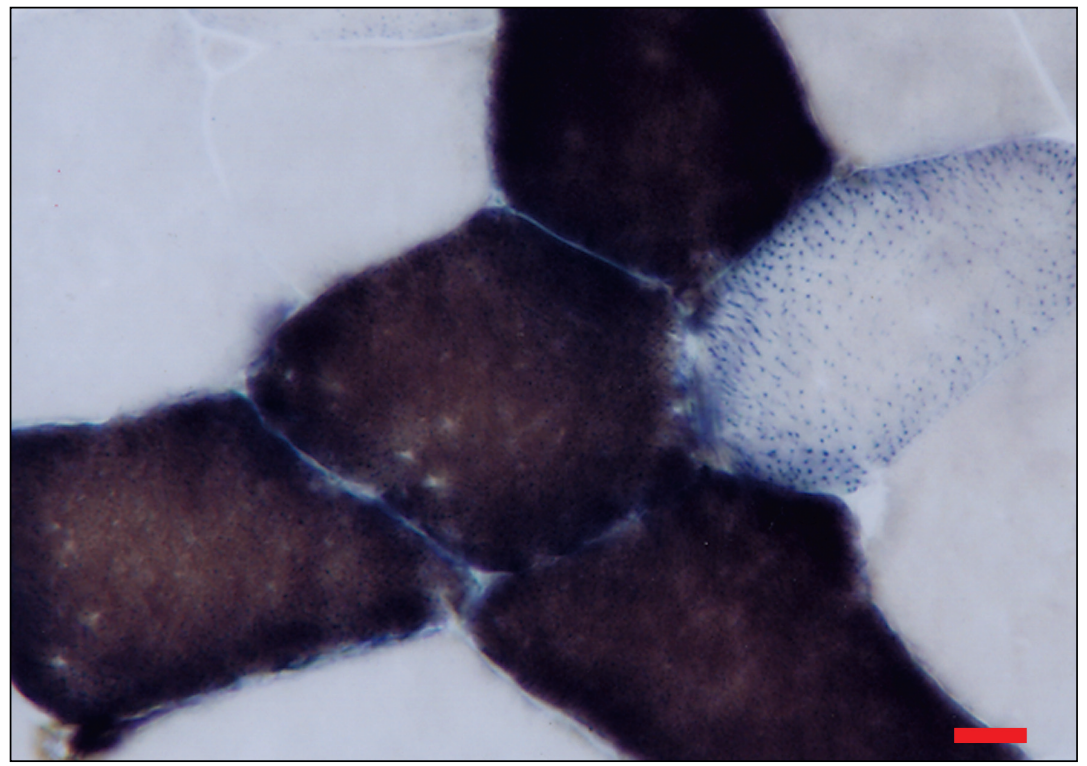

Fig. 5. M. longissimus dorsi (male). Light microscopy, m-ATPase + SDH histochemical staining of skeletal myofibres revealing three myofibre types: slow oxidative (SO, darkest); fast oxidative glycolytic (FOG, intermediate intensity) and fast glycolytic (FG, lightest). Transverse section, bar $=25 \mu \mathrm{m}$

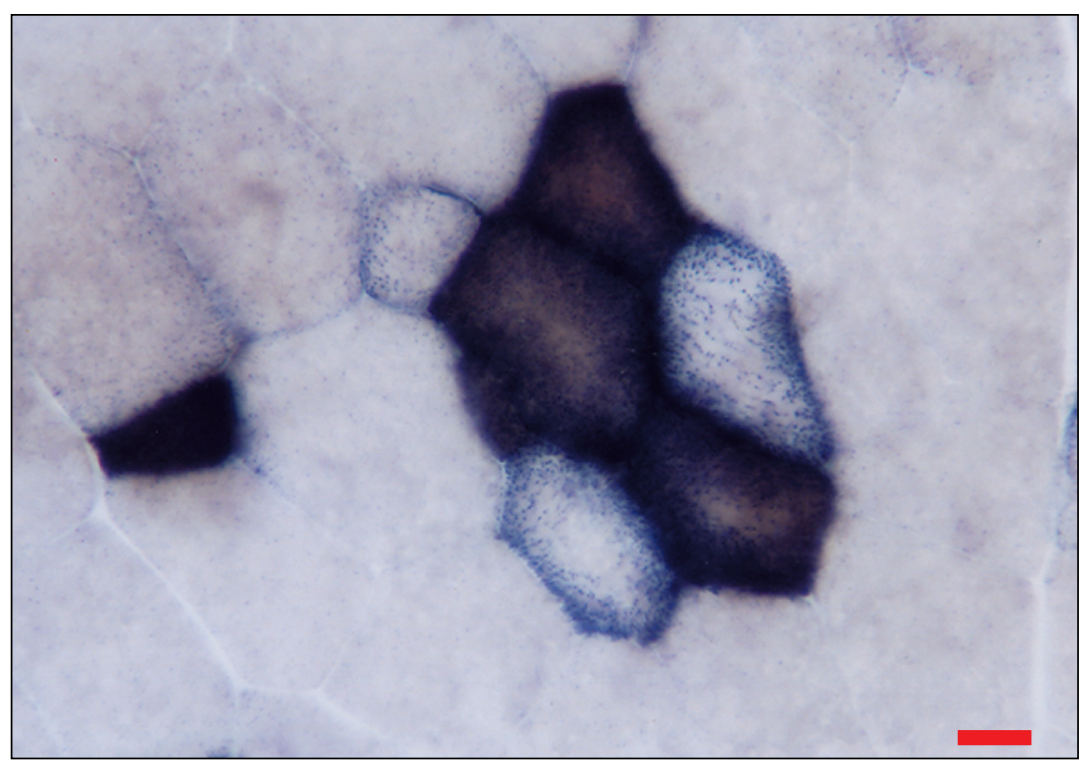

Fig. 6. M. longissimus dorsi (female). Light microscopy, m-ATPase + SDH histochemical staining of skeletal myofibres revealing three myofibre types: slow oxidative (SO, darkest); fast oxidative glycolytic (FOG, intermediate intensity) and fast glycolytic (FG, lightest). Transverse section, bar $=40 \mu \mathrm{m}$ 